\title{
“MAHKOTA UNTUK PEREMPUAN DI PROGRAM PEMBERDAYAAN": STUDI POSISI PENTING PEREMPUAN PADA PROGRAM PENGENTASAN KEMISKINAN DI KABUPATEN BANYUMAS
}

\author{
“Crown for Women on Empowerment Program": Studies of Important Position of Women \\ in Poverty Alleviation Program in Banyumas
}

\author{
Dwiyanto Indiahono*) \\ Ilmu Administrasi Negara, FISIP, Universitas Jenderal Soedirman \\ *) E-mail: dwiyanto.indiahono@unsoed.ac.id
}

\begin{abstract}
Women in rural areas with low education and experience are feared to be problems on poverty alleviation programs. Research forwomen position in poverty alleviation programs based onPNPM-Mandiri Perdesaan (rural empowerment) thus becomes strategic. This research seeks to find out, how the role of women in poverty programs?; and how important is the position of women in poverty alleviation programs?. Qualitative research has been carried out by conducting in-depth interviews and focus group discussion (FGD) to the members of women's groups, activists, actors and managers of PNPM-Mandiri Perdesaan in Banyumas Regency. Triangulation and interactive data analysis has been carried out strictly and carefully. The results showed that social capital of women groups has proven to be a major force to support the success of the poverty alleviation program. This makes the position of women is very important in this program. The important position is characterized by a strong social capital, unity of purpose, solidarity of groups, an excellent adaptation to change, and internalization of the program so that the objectives can be achieved.This study believes that the inclusion of women in poverty alleviation programs in rural areas is one of the best ways.
\end{abstract}

Keywords: development, empowerment, poverty, social capital, and women.

\begin{abstract}
ABSTRAK
Perempuan di daerah pedesaan dengan pendidikan dan pengalaman yang rendah dikhawatirkan menjadi masalah pada program pengentasan kemiskinan. Penelitian tentang posisi penting perempuan dalam program pengentasan kemiskinan berbasis PNPMMandiri Perdesaan (pemberdayaan pedesaan) menjadi strategis. Penelitian ini mengungkapkan, bagaimanakah peran perempuan dalam program pengembangan pengentasan kemiskinan?; dan seberapa pentingkah posisi perempuan dalam program pengentasan kemiskinan?. Penelitian kualitatif telah dilakukan dengan melakukan wawancara mendalam dan focus group discussion (FGD) dengan anggota perempuan kelompok, aktivis, aktor dan manajer kegiatan PNPM-Mandiri Perdesaan di Kabupaten Banyumas. Triangulasi dan analisis data interaktif telah dilakukan secara ketat dan hati-hati. Hasil penelitian menunjukkan bahwa modal sosial kelompok perempuan telah terbukti menjadi kekuatan utama yang mendukung keberhasilan program pengentasan kemiskinan. Hal ini membuat posisi perempuan sangat penting dalam program ini. Posisi penting ini ditandai dengan modal yang kuat sosial, kesatuan tujuan, solidaritas kelompok, adaptasi yang sangat baik untuk perubahan, serta internalisasi program sehingga tujuan dapat dicapai. Penelitian ini percaya bahwa melibatkan perempuan pedesaan dalam program pengentasan kemiskinan di akar rumput pedesaan adalah salah satu cara terbaik.
\end{abstract}

Kata kunci: pembangunan, pemberdayaan, kemiskinan, modal sosial, dan perempuan.

\section{LATAR BELAKANG}

Salah satu tujuan negara Republik Indonesia adalah untuk memajukan kesejahteraan umum. Hal inilah yang kemudian menjadikan tugas untuk menyejahterakan rakyat Indonesia menjadi salah satu pokok penting tujuan berbangsa dan bernegara. Hal ini diperkuat dengan salah satu sila dari Pancasila adalah Keadilan Sosial bagi Seluruh Rakyat Indonesia.

Pembangunan sejak berdirinya negara selalu diarahkan untuk mengentaskan kemiskinan. Dinamika pembangunan di Indonesia pun menjadi lebih menarik karena dinamika perubahan sosial, dinamika politik dan dinamika struktur ekonomi yang amat dinamis, selalu berubah dan heterogen. Pembangunan di masa orde baru dilakukan secara amat enerjik dengan melakukan pembangunan berpendekatan tangan besi pemerintah pusat.
Pemerintah pusat dengan kemampuan teknokratisnya merasa pihak yang selalu lebih paham dari masyarakat lokal dalam pembangunan. Pendekatan top down menjadi pilihan terbaik untuk menyelenggarakan pembangunan. Pembangunan yang top down pun kemudian runtuh seiring dengan runtuhnya kekuatan politik Presiden Soeharto, dan terganti dengan era reformasi yang lebih demokratis.

Pembangunan di era reformasi-demokrasi pun berlangsung di kutub yang berbeda dengan sebelumnya. Pendekatan bottom up kemudian dicoba sebagai pilihan terbaik dalam melakukan pembangunan. Masyarakat lokal diikutsertakan dalam program pemerintah dengan asumsi bahwa masyarakat lokal adalah pihak yang paling mengetahui potensi, dan metode untuk bangkit dari kelemahan untuk mencapai kesejahteraan. Pemerintah pun menggulirkan program pembangunan pengentasan kemiskinan 
Tabel 1. Jumlah dan Persentase Penduduk Miskin Indonesia Tahun 2007-2014

\begin{tabular}{cccr}
\hline $\begin{array}{c}\text { Tahun } \\
\text { Kota }\end{array}$ & \multicolumn{3}{c}{ Jumlah Penduduk Miskin (000) } \\
Kota & \multicolumn{1}{c}{ Desa } & Kota+Desa \\
\hline Sept - 2014 & $10.356,69$ & $17.371,09$ & $27.727,78$ \\
Mar - 2014 & $10.507,20$ & $17.772,81$ & $28.280,01$ \\
Sept - 2013 & $10.634,47$ & $17.919,46$ & $28.553,93$ \\
Mar - 2013 & $10.325,53$ & $17.741,03$ & $28.066,55$ \\
Sept - 2012 & $10.507,80$ & $18.086,90$ & $28.594,60$ \\
Mar - 2012 & $10.647,20$ & $18.485,20$ & $29.132,40$ \\
2011 & $11.046,75$ & $18.972,18$ & $30.018,93$ \\
2010 & $11.097,80$ & $19.925,60$ & $31.023,40$ \\
2009 & $11.910,50$ & $20.619,40$ & $32.530,00$ \\
2008 & $12.768,50$ & $22.194,80$ & $34.963,30$ \\
2007 & $13.559,30$ & $23.609,00$ & $37.168,30$ \\
\hline
\end{tabular}

Sumber: BPS 2015.

berpendekatan pemberdayaan. Program pengentasan kemiskinan berpendekatan pemberdayaan menjadi menarik untuk dikaji setidaknya karena dua hal, yaitu:

Pertama, program pemberdayaan hadir di saat kondisi Indonesia masih diselimuti kabut tebal kemiskinan terutama di pedesaan. Berikut adalah data kemiskinan di Indonesia dalam delapan tahun terakhir.

Kedua, program pemberdayaan hadir di saat Indonesia mulai melihat kaum perempuan sebagai modal pembangunan yang handal. Perempuan yang di masa lalu tidak pernah dilibatkan dalam program pembangunan pengentasan kemiskinan, dalam era reformasi-demokrasi dirangkul untuk terlibat dalam program. Hal ini menjadi penting dan menarik untuk dikaji untuk mengetahui apakah kaum perempuan mampu membuktikan dirinya sebagai kelompok yang dapat diandalkan dalam pembangunan. Teerakul, dkk (2012: 8) menunjukkan peran penting perempuan dalam pengentasan kemiskinan. Penelitiannya menunjukkan bahwa Communitybased Enterprises' (CBEs') harus didefinisikan sebagai bisnis/ perusahaan yang dimiliki dan didominasi oleh sekelompok orang, khususnya perempuan dalam sebuah komunitas.

Kajian peran perempuan dalam pengentasan kemiskinan ini menjadi amat penting sebab kaum perempuan ternyata menghadapi masalah dalam membangun bisnis. Keinginan untuk mandiri secara finansial dan pengambilan keputusan, pasar dan jaringan informasi, ketersediaan modal, pengetahuan start-up dan keterampilan, serta tanggung jawab terhadap anak-anak adalah faktor utama yang mempengaruhi keputusan perempuan untuk menjadi pengusaha (Hossain, 2009: 202). Perempuan memiliki dilema lebih dalam hal investasi bisnis, investasi dalam keluarga dan waktu untuk anak-anak (McKeen dan Burke, 1994: 24). Terlebih menurut Garikipati (201: 719) pinjaman perempuan adalahbiasanya digunakan untuk meningkatkan kepemilikan laki-laki dalam rumah tangga. Bank Dunia menggunakan sampel dari 40 negara berkembang dan telah menemukan bahwa sebagian kecil dari penduduk di bawah garis kemiskinan adalah linear tergantung pada jenis kelamin, rasio paritas di sekolah dasar dan menengah, prevalensi kekurangan gizi di kalangan anak, paritas daya beli per kapita, pendapatan kotor nasional, angka kematian ibu, dan persentase persalinan yang ditolong oleh tenaga kesehatan yang
Tabel 2. Jumlah dan Persentase Penduduk Miskin Kabupaten Banyumas 2008-2013

\begin{tabular}{cccc}
\hline Tahun & $\begin{array}{c}\text { Penduduk } \\
\text { Miskin } \\
\text { (000 jiwa) }\end{array}$ & Menduduk & $\begin{array}{c}\text { Garis } \\
\text { Kemiskinan } \\
\text { (Rp/kapita/ } \\
\text { Bulan) }\end{array}$ \\
\hline 2008 & 340,7 & 22,93 & 189.735 \\
2009 & 319,8 & 21,52 & 208.583 \\
2010 & 314,2 & 20,20 & 225.546 \\
2011 & 328,5 & 21,11 & 249.807 \\
2012 & 309,8 & 19,44 & 271.800 \\
2013 & 296,8 & 18,44 & 295.742 \\
\hline Sumber: BPS Kabupaten Banyumas 2015 &
\end{tabular}

terampil (Dao, 2008: 294). Tidak mengherankan jika Dwyer (2007: 1351) menyatakan bahwa kebijakan pertumbuhan pro orang miskin harus melibatkan perempuan dan kebijakan di tempat tersebut harus selaras dengan isu-isu sosial, lingkungan dan politik serta isu-isu ekonomi. Hal inilah yang menjadikan perempuan merupakan pihak yang harus dijadikan subjek dan objek dalam pembangunan khususnya pada program pengentasan kemiskinan. Sudah waktunya mengakui bahwa perempuan merupakan bagian penting dari perekonomian, untuk merangkul potensi yang mereka tawarkan (Thierry, 2007: 1372). Perempuan secara empirik diyakini memiliki andil yang signifikan pada pertumbuhan ekonomi(Park, 1993: 127). Kondisi di atas dalam konteks Kabupaten Banyumas menjadi menarik untuk dikajikarena kemiskinan di Kabupaten Banyumas masih cukup tinggi. Berikut adalah data kemiskinan di Kabupaten Banyumas dalam beberapa tahun terakhir.

Perlawanan terhadap kemiskinan di Kabupaten Banyumas salah satunya dilakukan dengan menggulirkan program pengentasan kemiskinan berbasis pemberdayaan: Program Nasional Pemberdayaan Masyarakat - Mandiri Perdesaan (PNPM-Mandiri Perdesaan). Selama kurun waktu 20082010, Pemerintah Kabupaten Banyumas menyatakan bahwa kemiskinan dapat terkoreksi kurang lebih tiga persen akibat dampak dari suksesnya PNPM Mandiri Perdesaan. Hal ini menunjukkan bahwa secara sederhana PNPM Mandiri Perdesaan di Kabupaten Banyumas berjalan dengan baik. Salah satu pendukung suksesnya PNPM Mandiri Perdesaan di Kabupaten Banyumas adalah kehadiran kelompok perempuan dalam kegiatan Simpan Pinjam Kelompok Perempuan (SPP). Kim (2012: 71) menyatakan bahwa microenterprise development programs (mirip dengan SPP dan Usaha Ekonomi Produktif (UEP) dalam PNPM Mandiri Perdesaan) dapat menunjukkan faktor unik perempuan yang dapat dikonversi dalam hal keuangan, manusia, modal sosial, dan diskriminasi jender yang terstruktur, dan seberapa efektif mereka dalam membantu perempuan untuk meningkatkan kemampuan mereka.

Kehadiran kelompok perempuan dalam program pengentasan kemiskinan di perdesaan sejak awalnya mengalami keraguan yang besar.Hal ini karena di kala masyarakat lebih bersifat patriarki, yang lebih mendahulukan anak laki-laki untuk mendapatkan akses pendidikan, maka perempuan di perdesaan dapat dipastikan memiliki tingkat pendidikan dan "pengalaman hidup" yang lebih rendah dari kaum laki-laki. Hal inilah yang menjadikan perubahan sumber daya sosial (social and human capital) dalam pembangunan perempuan lebih penting dari pada perubahan sumber daya material (Eber dan Tanski, 2001; Howell, 2002; Campion Pathways dan Shrum, 2004: 459; dan 
Hong dan Pandai, 2007). Pendidikan dan pengalaman yang rendah itulah yang menjadikan kaum perempuan diragukan posisinya dalam program pengentasan kemiskinan PNPM Mandiri Perdesaan. Hal inilah yang menjadikan studi tentang perempuan dalam program pengentasan kemiskinan PNPM Mandiri Perdesaan menarik untuk dilakukan. Penelitian ini hendak mengungkap, bagaimanakah peran perempuan dalam program pemberdayaan pengentasan kemiskinan?; dan seberapa pentingkah posisi perempuan dalam menyukseskan program pengentasan kemiskinan?.

Penelitian ini menjadi penting guna mengetahui peran dan posisi penting kaum perempuan dalam program pengentasan kemiskinan PNPM Mandiri Perdesaan di Kabupaten Banyumas. Hasil penelitian ini dapat dijadikan dasar untuk meletakkan perempuan pada porsi yang tepat dalam program pengentasan kemiskinan yang serupa di Indonesia. Selain itu, hasil penelitian yang didapatkan dari lapangan yang empirik dapat menambah kaya khasanah studi perempuan dalam pembangunan di Indonesia baik untuk kepentingan teoritis maupun praktis. Secara teoritik dan konseptual penelitian ini juga akan turut menyumbang kajian kredit mikro di kalangan perempuan yang selama ini diidentifikasi oleh Drolet (2010) terdapat tiga paradigma: the financial self-sustainability, poverty alleviation, and feminist empowerment paradigms.

\section{METODE PENELITIAN}

Penelitian Studi Posisi Penting Perempuan pada Program Pengentasan Kemiskinan (PNPM Mandiri Perdesaan) di Kabupaten Banyumas ini menggunakan metode penelitian kualitatif. Pendekatan kualitatif diyakini dapat lebih menjelaskan, memberikan pengertian, serta menggali penyebab, alasan-alasan hingga ke akar-akarnya (Sriyuningsih, 2003). Tipe penelitian kualitatif dalam penelitian ini tepat digunakan karena hendak mengkonstruksi pengetahuan masyarakat secara lebih sistematik, guna dipahami oleh masyarakat itu sendiri (Bungin, 2001: 8). Tipe penelitian kualitatif lebih sesuai karena dapat mengungkap keunikan individu, kelompok, masyarakat, dan atau organisasi tertentu dalam kehidupannya sehari-hari secara komprehensif dan serinci mungkin (Basrowi dan Sukidin, 2002: 2, dan Dawson, 2002: 14). Penelitian kualitatif telah dilakukan di tiga kecamatan di Kabupaten Banyumas, yaitu Kecamatan Ajibarang, Kedung Banteng dan Sumbang. Teknik pengumpulan data adalah dengan melakukan wawancara mendalam dan focus group discussion (FGD) yang diikuti oleh para anggota kelompok perempuan, pegiat, pelaku dan pengelola kegiatan PNPM Mandiri Perdesaanserta teknik dokumentasi. Triangulasi dilakukan dengan teknik memverifikasi pernyataan antar individu, individu saat wawancara dengan saat FGD, serta pernyataan dengan dokumen yang ada. Teknik analisis data yang digunakan adalah teknik analisis data interaktitf.

\section{HASIL DAN PEMBAHASAN}

Pemberdayaan perempuan merupakan istilah yang muncul karena faktor ideologis. Pemberdayaan perempuan lahir karena program pembangunan yang berpendekatantop down dianggap tidak lagi mampu untuk menjawab permasalahan pembangunan dan menjadi kerdil di tengah-tengah masyarakat yang heterogen. Program pemberdayaan kemudian memberikan ruang yang cukup bagi kaum perempuan untuk berekspresi dan menunjukkan modal sosial yang mereka miliki. Modal sosial perempuan inilah yang coba dibangun dalam kerangka Program Nasional Pemberdayaan Masyarakat (PNPM) Mandiri Perdesaan. Modal sosial perempuan yang kuat dalam kelompokkelompok kemudian dikembangkan menjadi modal untuk maju dan berkembang secara ekonomi. Ekonomi yang dikembangkan kemudian benar-benar mencirikan aktivitas mereka sebagai paguyuban, informal, namun tetap efektif dalam melaksanakan kegiatan.Banyak kajian menunjukkan bahwa modal sosial merupakan modal bagi orang miskin untuk bertahan hidup, mengembangkan kemampuan ekonomi dan mengembangkan komunitas (community development) (Grootaert and Bastelaer, 2002; Wallis and Dollery, 2002; Gertler, dkk, 2006; Welshman, 2006; Resnick and Birner, 2006; Jian, 2014; serta Aldrich dan Meyer, 2014). Temuan Barlan(2014: 115), menunjukkan bahwa paguyuban petani memiliki hubungan yang sangat lemah dengan kesejahteraan ekonomimasyarakat, tetapi memiliki hubungan yang cukup kuat dengan kesejahteraan sosial masyarakat.

Kelompok-kelompok perempuan yang beraktifitas dalam kegiatan Simpan Pinjam Kelompok Perempuan (SPP) memang dapat dibedakan menjadi dua jenis: kelompok lama dan kelompok baru. Kelompok lama adalah kelompok perempuan yang memang telah berdiri lama, memiliki ikatan emosi dalam kelompok dan biasanya telah memiliki aktifis yang militan dan terdidik. Kelompok seperti ini diwakili oleh kelompok pengajian, kelompok tahlil, kelompok PKK dan kelompok dasa wisma. Kelompok kedua adalah kelompok baru yang baru berdiri sejak program digulirkan. Kelompok ini biasanya didirikan karena adanya kepentingan untuk berusaha, memberdayakan potensi yang ada dan berusaha keras untuk membuat proposal sehingga mendapatkan dana untuk berkegiatan dalam bidang ekonomi. Kedua kelompok tersebut, meskipun dapat dibedakan, namun secara modal sosial mereka memiliki kekuatan yang hampir sama. Mereka senantiasa berkeinginan kuat untuk belajar dan terus berkembang untuk mengembangkan program PNPM Mandiri Perdesaan.

Program PNPM Mandiri Perdesaan khususnya untuk kelompok perempuan merupakan contoh terbaik dalam pengelolaan aset dalam program pengentasan kemiskinan. Mereka kebanyakan memang terdiri dari para ibu rumah tangga, namun mereka adalah orang-orang yang amat bertanggung jawab terhadap program. Hal ini terbukti dengan kemauan mereka untuk bersusah payah dalam merancang kegiatan ekonomi dalam kelompok, menyisihkan waktu untuk berserikat dan berorganisasi serta mau bersusah payah untuk menagih anggota kelompok yang "bandel" yang terlambat membayar kewajiban dalam kelompok. Kegigihan perempuan-perempuan ini serupa dengan kegigihan perempuan dalam angkatan kerja pertanian yang memainkan peran penting dalam meningkatkan nilai tambah pekerja pertanian di negara-negara berkembang (Dao, 2009: 182).

Ibu-ibu dari desa itu meskipun dari latar belakang pendidikan yang rendah tetap mau berusaha untuk membuat proposal guna mendapatkan bantuan dalam PNPM Mandiri Perdesaan. Hal inilah yang kemudian memicu mereka membutuhkan agen of change dari golongan berpendidikan, padahal orang yang berpendidikan di desa adalah orang-orang mampu. Orangorang mampu di desa ini kemudian masuk dalam kelompok, memberikan transfer ilmu pengetahuan dan terkadang harus berkorban untuk menalangi kredit yang macet. Masuknya orang menengah dalam PNPM Mandiri Perdesaan sebenarnya tidaklah diharapkan, tetapi hal ini tidak serta merta memberikan klaim bahwa aktifitas PNPM Mandiri Perdesaan tersebut telah gagal. Masuknya orang menengah dalam program PNPM Mandiri Perdesaan tersebut harus dipandangsebagai mekanisme survivalitas warga miskin untuk melanggengkan program. Terlebih orang menengah yang masuk dalam kelompok bukanlah orang yang akan menghisap kaum miskin di sekitarnya, justeru kehadiran mereka adalah sebagai agent of 


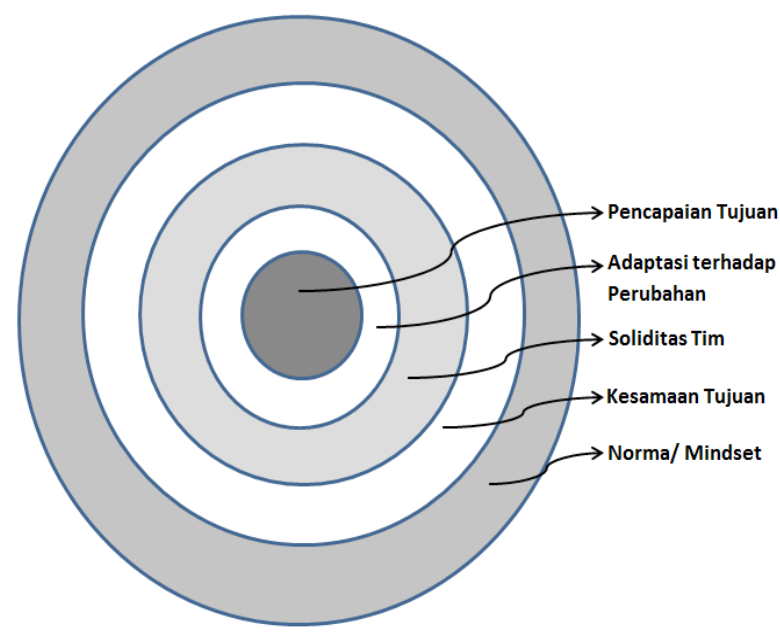

Gambar 1. Peran Penting Modal Sosial Perempuan dalam Program Pengentasan Kemiskinan

change dan "guru" terbaik bagi kaum miskin. Kaum menengah tersebut dapat dengan secara elegan berperan sebagai guru yang mengajarkan nilai-nilai organisasi, menyampaikan perkembangan ilmu pengetahuan terkini serta "tameng" di kala ada kredit macet. Hal ini nampaknya selaras dengan temuan Campbell and Teghtsoonian (2010: 176), yang menyatakan bahwa bantuan dapat bekerja secara efektif karena kebijakan dibingkai untuk mengarahkan orang (kelompok sasaran) untuk menafsirkan kehidupan dan pengalaman mereka dengan cara tertentu dan belajar untuk mengambil tindakan yang tepat untuk itu.

Para ibu-ibu tersebut amat semangat untuk mengikuti pertemuan-pertemuan dalam PNPM Mandiri Perdesaan. Pertemuan-pertemuan tersebut harus dimaknai sebagai upaya untuk melepaskan ekspresi, menunjukkan eksistensi diri, melepaskan stres, juga bermanfaat untuk mengeratkan ikatan sosial. Ikatan sosial yang erat inilah yang kemudian akan secara otomatis mengamankan program. Aset program dalam bentuk dana simpan pinjam akan aman karena antar anggota kelompok tumbuh sikap saling percaya, saling memahami dan saling tolong menolong. Para "atasan" dari kelompok-kelompok tersebut kebanyakan juga perempuan. Para perempuan yang ada di atas pun berdasarkan sifatnya amat percaya dengan kelompok-kelompok yang telah ada. "Jangan pernah ada dusta diantara kita" begitulah penggambarannya. Para perempuan yang ada di atas, jika ada anggota kelompok atau kelompok yang terlambat membayar angsuran, akan mencoba menelaah apa yang harus dilakukan, apakah tindakan pengabaian (karena yakin pasti akan dibayar), tindakan memberi dispensasi (pemotongan angsuran), atau bahkan tindakan represi (tindakan yang paling ekstrim adalah didatangi rumahnya).

Pendidikan dan pelatihan pada kaum perempuan selama ini dipengaruhi oleh faktor individual dan organisasi (Harris dan Leberman, 2012: 28). Forum PNPM Mandiri Perdesaan dengan demikian telah berperan sangat baik dalam rangka membangun human capital pada aspek kepemimpinan. Para perempuan belajar dari orang yang ada di sekelilingnya tentang manajemen dan kepemimpinan. Para perempuan juga semakin berani mengutarakan pendapat dan gagasan dalam berbagai forum yang ada di desa. Hal ini menjadi penting sebab beberapa penulis mengkhawatirkan wanita saat ini membuat pilihan untuk tidak bercita-cita dalam posisi kepemimpinan(Hoobler, dkk, 2014: 703).
Kaum perempuan di perdesaan yang mengikuti program SPP mengakui bahwa tidak sepenuhnya uang yang dipinjam adalah untuk usaha produktif. Hal ini sebenarnya sedikit melenceng dari keinginan program yang hendak meningkatkan taraf ekonomi warga, namun bukan berarti ini adalah kegagalan total. Konsep pengentasan kemiskinan secara ekonomi sebenarnya berkisar pada dua hal, yaitu menambah pendapatan dan memperkecil pengeluaran. Bentuk uang segar yang ditawarkan oleh PNPM Mandiri Perdesaan kepada kaum perempuan sebenarnya bentuk dari upaya meningkatkan sisi pendapatan meskipun dalam waktu yang sangat singkat. Hal ini merupakan sikap rasional kaum miskin untuk bertahan hidup, dan PNPM Mandiri Perdesaan benar-benar menjadi makhluk setengah dewa dalam menyelamatkan dapur dan kebutuhan hidup mereka untuk sementara. Bantuan kredit mikro memang seharusnya dapat menjadi proses intermediasi sosial dan membangun modal sosial (Hassan, 2014: 77). Proses intermediasi sosial yang dimaksud adalah membuka akses kaum miskin yang tidak memiliki aset untuk dapat mengakses pinjaman. Pinjaman dari hasil ini diharapkan mampu menjadi kelompok yang mandiri.

Modalsosial merupakan sumber daya yang berguna, yang memfasilitasi interaksi sosial dan mempromosikan dukungan dan kerjasama yang dapat meningkatkan pendapatan, tata kelola masyarakat yang lebih baik dan peningkatan kapasitas (Bhuiyan, 2011). Program pemberian kredit kepada kaum perempuan mampu meningkatkan partisipasi kaum perempuan dalam pengambilan keputusan rumah tangga, membantu klien mencapai tingkat keamanan ekonomi, mendapatkan kontrol lebih besar atas sumber daya dan keputusan keluarga, meningkatkan kemampuan pergi ke luar untuk bekerja dan meningkatkan tingkat kesadaran hukum (Al-Mamun dkk, 2014a; dan 2014b; Mukherjee dan Kundu, 2012). Manajemen kelompok dari kelompok sasaran untuk mengembangkan komunitas seharusnya juga diperhatikan sebagai faktor utama, selain faktor kredit mikro (Moniruzzaman, 2011).Sehingga, sebagian kaum feminis mengusulkan dalam program kredit mikro ada istilah "mikro kredit plus", yaitu pemberian kredit juga diiringi dengan program untuk peningkatan kesehatan sosioemosional (self-confidence, self-efficacy, and social relationships), peningkatan aset ekonomi, dan peningkatan kesetaraan gender dalam rumah tangga (Krenz dkk, 2014). Hal ini selaras dengan Narotzky dan Besnier (2014: S4), yang menyatakan bahwa "making in living" adalah tentang membuat orang berada pada situasi yang nyaman pada fisik, sosial, spiritual, afektif, dan dimensi intelektual mereka.

Partisipasi masyarakat dalam bentuk modal sosial pada pembangunan pedesaan semakin memperoleh penerimaan sebagai instrumen penting untukmemobilisasi sumber dayadan mengaturrakyatpedesaan dalam rangka memperoleh kesejahteraan (Emeh dkk, 2012; Iyengar, 2012; dan Carr, 2008). Modal sosial juga berpengaruh pada tingkat partisipasi masyarakat dalam menyelesaikan masalah-masalah pembangunan (Kang Hu dan Chan, 2012). Studi Sangole dkk (2014) menunjukkan bahwa kelompok tani terpadu yang berpartisipasi dalam pemantauan dan evaluasi memiliki indeks yang tinggi untuk modal sosial dan kinerja kelompok. Kelompok-kelompok ini menunjukkan kohesi kelompok yang lebih besar dan anggota memiliki kepuasan yang lebih tinggi terhadap kinerja kelompok.

Penelitian ini menemukan bahwa kaum ibu perdesaan menunjukkan kepedulian yang besar kepada kehidupan yang layak di keluarga mereka. Uang yang seharusnya untuk usaha produktif, seringkali dialokasikan untuk membeli keperluan dapur, lebaran dan kepentingan sekolah anak-anak. Kaum 
ibu anggota PNPM Mandiri Perdesaan yang mengalokasikan uangnya untuk konsumtif adalah mereka yang berasal dari golongan tidak mampu atau miskin. Hal ini terjadi karena mereka benar-benar membutuhkan jaring pengaman untuk melangsungkan hidup secara layak, dan PNPM Mandiri Perdesaan telah melakukannya dengan baik.Pemberian kredit kepada kaum miskin bukanlah upaya permanen untuk mengurangi kemiskinan, namun pemberian kredit kepada kaum miskin adalah upaya untuk menghindari kerentanan kaum miskin dari kemiskinan (Shetty, 2010; serta Develtere dan An Huybrechts, 2005). Pinjaman dalam bentuk uang segar tersebut harus dilakukan secara hati-hati, agar pinjaman dari program mikro kredit ini tidak menjadi jebakan atas kemiskinan baru (Gehlich-Shillabeer, 2008: 396). Terlebih, temuan Akudugu (2011) menunjukkan bahwa para petani perempuan yang mendapatkan modal dari kredit bank desa telah memiliki kontribusi positif terhadap pengembangan mata pencaharian perempuan dan masyarakat miskin pada umumnya. Kaum petani perempuan mengalami perbaikan yang signifikan dalam akses mereka terhadap pelayanan kesehatan, pendidikan dan peningkatan pendapatan, sedangkan di sisi yang lain nonpenerima manfaat hanya mendapatkan perbaikan yang marjinal. Kredit mikro yang berhasil akan menambah tabungan, aset dan kesejahteraan sosial (Siringi, 2011: 186). Penting untuk merekomendasikan peningkatan keikutsertaan kelompok perempuan pada program-program pengentasan kemiskinan (Akhtar, 1997: 302; dan Moyo, 2014).

Berdasarkan penelitian ditemukan beberapa faktor yang menjadikan perempuan memiliki peran penting dalam pencapaian tujuan program pengentasan kemiskinan PNPM Mandiri Perdesaan(Lihat Gambar 1).Pertama, Norma/Mindset. Kelompok perempuan di perdesaan memiliki norma yang sama, atau dalam bahasa konseptual disebut memiliki modal sosial yang kuat. Norma atau nilai yang unggul tersebut adalah saling tolong menolong, saling menghargai, guyub,saling percaya, tanggung jawab dan saling tenggang rasa. Nilai-nilai inilah yang merupakan modal terkuat yang dimiliki kaum perempuan dalam program PNPM Mandiri Perdesaan yang hendak melakukan pemberdayaan di kalangan akar rumput.Hal yang terjadi di Kabupaten Banyumas ini tentu tidak seperti yang terjadi di Nigeria yang gagal mengimplementasikan kredit untuk usaha kecil dan menengah karena skill yang rendah, perilaku korup dan rendahnya daya dukung pemerintah (Nkamnebe dan Idemobi, 2011: 236). Nilai merupakan hal penting dalam pelibatan perempuan dalam pengentasan kemiskinan, sebab modal sosial menurut Coleman (1988: 95) terdiri dari tiga bentuk: kewajiban dan harapan, saluran informasi, dan norma-norma sosial. Kajian ini berhasil menunjukkan bahwa perempuan pedesaan memiliki modal sosial yang kuat, karena mereka memiliki ketiga bentuk modal sosial tersebut.

Kedua, Kesamaan Tujuan. Modal sosial yang kuat kemudian memudahkan mereka untuk merancang tujuan yang sama dalam kerangka program PNPM Mandiri Perdesaan. Kesamaan tujuan untuk bersama-sama maju dan berkembang dengan diiringi dengan sikap mengedepankan norma-norma yang mereka miliki kemudian menjadikan tujuan kelompok menjadi ter-internalisasi secara kokoh dalam setiap anggota dan pelaku PNPM Mandiri Perdesaan. Internalisasi tujuan program ke dalam tubuh masingmasing anggota merupakan kunci keberhasilan dalam program pengentasan kemiskinan. Kesamaan tujuan ini merupakan buah dari partisipasi sosial dan kerjasama berdasarkan kepercayaan sosial dipertahankan untuk menjaga jaringan tetap terhubung pada sistem nilai bersama dan norma-norma moral (WalczakDuraj, 2010: 429).
Ketiga, Soliditas Tim. Kesamaan tujuan kemudian mengarahkan kelompok untuk senantiasa bergerak mencapai tujuan. Tujuanlah yang mengarahkan kelompok untuk berpacu dengan waktu, enerjik dan inovatif untuk terus mengembangkan program. Pemantauan program yang lahir dari nilai, tujuan dan soliditas tim inilah yang menyebabkan perempuan merupakan pihak yang bertanggung jawab dalam program . Hal ini serupa dengan temuan dari Siddique (1998: 1109) yang mengemukakan bahwa perempuan merupakan pihak yang bertanggung jawab dalam hal mengimplementasikan dan memantau program kemiskinan di kalangan mereka sendiri.

Keempat, Adaptasi terhadap Perubahan. Soliditas tim kemudian mengarahkan kelompok perempuan dan anggotanya untuk senantiasa berpikir terhadap perubahan dan siap sedia untuk melakukan adaptasi terhadap perubahan program demi tercapainya tujuan. Para anggota dan pelaku PNPM Mandiri perdesaan sangat siap untuk melakukan inovasi program, karena program benar-benar telah dirasa menjadi bagian dari kehidupan mereka. Merekalah yang bertanggung jawab terhadap program, dan tak ada itikad buruk yang terbersit untuk sekedar melarikan uang program ke dalam kantong pribadi. Kaum perempuan yang memiliki modal sosial yang baik ini memanfaatkan jaringan yang ada untuk mengumpulkan informasi, dan mengajak person yang diyakini bertanggung jawab untuk masuk pada program. Hal ini hampir senada dengan Burt (1997: 358) menyatakan bahwa modal sosial dapat digunakan untuk mengetahui orangorang yang produktif yang dapat dibawa pada proyek-proyek baru.Modal sosial pun memiliki dampak positif bagi lahirnya kreasi dari kelompok (Han dkk., 2014).

Kelima, Pencapaian Tujuan. Norma yang baik, modal sosial yang kuat, tujuan yang jelas tim yang solid dan siap menerima perubahan untuk pengembangan program ternyata membawa mereka untuk mencapai tujuan program secara baik. Pencapaian program pemberdayaan sudah selayaknya diukur bukan hanya semata-mata dari perspektif pembuat atau penggagas program, tetapi juga harus dilihat dari perspektif pelaku. Anggota dan pelaku PNPM Mandiri Perdesaan telah berusaha sekuat tenaga untuk mencurahkan yang mereka bisa lakukan dalam program, kemandirian untuk mengelola, dan mengembangkan program sehingga dapat berjalan secara berkelanjutan adalah suatu keberhasilan yang besar. Keberhasilan program pengentasan kemiskinan berbasis pemberdayaan adalah ketika kelompok sasaran mampu berdikari di kaki sendiri dengan stimulasi program.

\section{KESIMPULAN DAN SARAN}

Penelitian Studi Posisi Penting Perempuan pada Program Pengentasan Kemiskinan (PNPM Mandiri Perdesaan) di Kabupaten Banyumas ini mengungkap bahwa perempuan memiliki posisi strategis dalam program pengentasan kemiskinan. Posisi penting ini ditunjukkan dengan hadirnya modal sosial, kesatuan tujuan, soliditas kelompok, adaptasi terhadap perubahan yang sangat baik, serta internalisasi program sehingga tujuan dapat tercapai. Penelitian ini meyakinkan bahwa melibatkan perempuan desa dalam program pengentasan kemiskinan di akar rumput pedesaan merupakan salah satu jalan terbaik dalam program serupa di masa depan.

\section{DAFTAR PUSTAKA}

Akhtar, Muhammad Ramzan and G. M. Arif. 2000. Poverty Alleviation on a Sustainable Basis in the Islamic Framework. The Pakistan Development Review. Vol 39/4, pp. 631-647. 
Akudugu, M.A.. 2011. Rural banks' financial capital and livelihoods development of women farmers in Ghana. Journal of Enterprising Communities: People and Places in the Global Economy. Vol 5/ 4, pp. 248 - 264.

Aldrich, Daniel P and Michelle A. Meyer. 2014. Social Capital and Community Resilience. American Behavioral Scientist. Vol 2014, pp. 1-16.

Al-Mamun, Abdullah; Mohammad Nurul Huda; Mazumder; dan C.A. Malarvizhi. 2014b. Measuring The Effect Of Amanah Ikhtiar Malaysia's Microcredit Programme On Economic Vulnerability Among Hardcore Poor Households. Progress in Development Studies. Vol 14/ 1, pp. 49-59.

Al-Mamun, Abdullah; Sazali Abdul Wahab; Mohammad Nurul Huda Mazumder; dan Zhan Su. 2014a. Empirical Investigation On The Impact Of Microcredit On Women Empowerment In Urban Peninsular Malaysia. The Journal of Developing Areas. Vol 48/ 2, pp. 287 306.

Barlan, Zessy Ardinal et al. 2014. Peran Paguyuban Dalam Pembangunan Kawasan Desa. Sodality: Jurnal Sosiologi Pedesaan. Vol. 02/02, pp. 115-123.

Basrowi dan Sukidin. 2002. Metode Penelitian Kualitatif Perspektif Mikro. Penerbit Insan Cendekia: Surabaya.

Bhuiyan, Shahjahan H. 2011. Social Capital and Community Development: An Analysis of Two Cases from India and Bangladesh. Journal of Asian and African Studies. Vol 46/ 6. Pp. 533-545.

Bungin, Burhan. 2001. Realitas Sosial dan Konstruksi Sosial. Bungin dan Burhan Bungin dalam Metodologi Penelitian Kualitatif: Aktualisasi Metodologis ke Arah Ragam Varian Kontemporer. PT RajaGrafindo Persada: Jakarta.

Burt, Ronald S. 1997. The Contingent Value of Social Capital. Administrative Science Quarterly. Vol 42/ 2, pp. 339365.

Campbell, Marie L. dan Katherine Teghtsoonian. 2010. Aid Effectiveness and Women's Empowerment: Practices of Governance in the Funding of International Development. Signs. Vol $36 / 1$, pp. 177-202.

Campion, Patricia dan Wesley Shrum. 2004. Gender and Science in Development: Women Scientists in Ghana, Kenya, and India. Science, Technology, \& Human Values. Vol 29/4, pp. 459-485.

Carr, Edward R. 2008. Rethinking Poverty Alleviation: A 'Poverties' Approach. Development in Practice. Vol 18/ 6, pp. 726-734.

Coleman, James S. 1988. Social Capital in the Creation of Human Capital. American Journal of Sociology. Vol 94/ 1988, pp. S95-S120.

Dao, Minh Quang. 2008. Human capital, poverty, and income distribution in developing countries. Journal of Economic Studies. Vol 35/ 4, pp. $294-303$.

Dao, Minh Quang. 2009. Poverty, income distribution, and agriculture in developing countries. Journal of Economic Studies. Vol 36/ 2, pp. $168-183$.

Dawson, Catherine. 2002. Practical Research Methods: A User-Friendly Guide To Mastering Research Techniques And Projects. How To Books - Printed and bound by Cromwell Press: Trowbridge, Wiltshire.

Develtere, Patrick; dan An Huybrechts. 2005. The Impact of Microcredit on the Poor in Bangladesh. Alternatives. Vol 2005/30, pp. 165-189.

Drolet, Julie. 2010. Feminist Perspectives in Development: Implications for Women and Microcredit. Journal of Women and Social Work. Vol 25/3, pp. 212-223.

Dwyer, Rocky J.. 2007. Alleviating poverty: how do we know the scope of the problem and when we have solved it?". Management Decision. Vol 45/ 8, pp. 1344 - 1358.

Eber, Christine E, dan Janet M. Tanski. 2001. Obstacles facing women's grassroots development strategies in Mexico. Review of Radical Political Economics. Vol 33/2001, pp. 441-460.

Emeh, Ikechukwu Eke Jeffry; Izubundu Jayce Eluwa; Finian Okechukwu Ukah. 2012. Rural-Community Development In Nigeria: A Group Dynamics Perspective. Interdisciplinary Journal of Contemporary Research in Business. Vol 4/5. pp. 1090-1107.

Garikipati, Supriya. 2012. Microcredit and Women's Empowerment: Through theLens of Time-Use Data from Rural India. Development and Change. Vol 43/ 3, pp. 719-750.

Gehlich-Shillabeer, Mareen. 2008. Poverty alleviation or poverty traps? Microcredits and vulnerability in Bangladesh. Disaster Prevention and Management: An International Journal. Vol 17/3, pp. 396- 409.

Gertler, Paul; David I Levine; and Enrico Moretti. 2006. Is Social Capital the Capital of the Poor? The Role of Family and Community in Helping Insure Living Standards against Health Shocks". CESifo Economic Studies. Vol 52/3, pp. 455-499.

Grootaert, Christiaan and Thierry van Bastelaer. 2002. Understanding and Social Capital: A Multidisciplinary Tool for Practitioners. The World Bank: Washington, D.C.

Han, Jing; Jian Han and Daniel J. Brass. 2014. Human Capital Diversity in the Creation of Social Capital for Team Creativity. Journal of Organizational Behavior. Vol 2014/35, pp. 54-71.

Harris, Candice A. dan Sarah I. Leberman. 2012. Leadership Development for Women in New Zealand Universities: Learning From the New Zealand Women in Leadership Program. Advances in Developing Human Resources. Vol 14/1, pp. 28-44.

Hassan, Abul. 2014. The challenge in poverty alleviation: role of Islamic microfinance and social capital. Humanomics. Vol 30/ 1, pp. $76-90$.

Hong, Philip Young P. dan Shanta Pandey. 2007. Human capital as structural vulnerability of US poverty. Equal Opportunities International. Vol 26/ 1, pp. 18-43.

Hoobler; Jenny M.; Grace Lemmon; dan Sandy J. Wayne. 2014. Women's Managerial Aspirations: An Organizational Development Perspective. Journal of Management. Vol 40/ 3, pp. 703-730.

Hossain, Amzad; Kamal Naser; Asif Zaman; dan Rana Nuseibeh. 2009. Factors influencing women business development in the developing countries Evidence from Bangladesh. International Journal of Organizational Analysis. Vol 17/3. 202-224.

Howell, Sharon L.; Vicki K. Carter dan Fred M. Schied. 2002. Gender And Women's Experience At Work: A Critical And Feminist Perspective On Human Resource Development. Adult Education Quarterly. Vol 52/2, pp. 112-127.

Iyengar, Radhika. 2012. Forms of Social Capital in India: A Case Study of Jhabua District. Journal of Asian and African Studies. 2012/47. pp. 710-733.

Jian, Titan Bo-xiu. 2014. The Incident of Tieben: Social Capital and Local Governance in Post-Socialist China. China Review. Vol 14/ 1, pp. 61-96.

Kang $\mathrm{Hu}$ dan Raymond K H Chan. 2012. Social Capital and Civic Engagement in Urban China. International Journal of Social Quality. Vol 2/ 2, pp. 24-42.

Kim, Seon Mi. 2012. Evaluations of Women-Centered U.S. 
Microenterprise Development Programs. Journal of Women and Social Work. Vol 27/ 1, pp. 71-83.

Krenz Kristin; Dorie J. Gilbert; dan Gokul Mandayam. 2014. Exploring Women's Empowerment Through "CreditPlus" Microfinance in India. Journal of Women and Social Work. Vol 29/3, pp. 310-325.

McKeen, Carol A. dan Ronald J. Burke. 1994. The Womanfriendly Organization. Employee Councelling Today. Vol 6/ 6, pp. 18-25.

Moniruzzaman, M. 2011. Group Management and Empowerment Lessons from Development NGOs in Bangladesh. Journal of South Asian Development. Vol 6/ 1, pp. $67-91$.

Moyo, Christabelle S. 2014. Active Participation of Rural Women in Developmental Issues: Poverty Alleviation Lessons for South Africa. Gender \& Behaviour. Vol 12/ 1, pp. 5994-6001.

Mukherjee, Arghya Kusum dan Amit Kundu. 2012. Microcredit and Women's Agency: A Comparative Perspective across Socioreligious Communities in West Bengal, India. Gender Technology and Development. Vol 2012/ 16, pp. 71-94.

Narotzky, Susana dan Niko Besnier. 2014. Crisis, Value, and Hope: Rethinking the Economy: An Introduction to Supplement 9. Current Anthropology, Vol. 55/ S9, pp. S4-S16.

Nkamnebe, Anayo D. dan Ellis I. Idemobi. 2011. Recovering of micro credit in Nigeria. Management Research Review. Vol 34/2, pp. 236- 247.

Park, Kyung Ae. 1993. Women and Development: The Case of South Korea. Comparative Politics. Vol 25/ 2, pp. 127-145.

Resnick, Danielle and Regina Birner. 2006. Does Good Governance Contribute to Pro-Poor Growth?: A Review of the Evidence from Cross-Country Studies. Development Strategy and Governance Division International Foor Policy Research Institute; Washington DC USA.
Sangole, N., Kaaria, S., Njuki, J., Lewa, K., \& Mapila, M. 2014.Community Based Participatory Monitoring And Evaluation: Impacts On Farmer Organization Functioning, Social Capital And Accountability. The Journal of Rural and Community Development. Vol 9/ 2, pp. 128-148.

Shetty. Sujata. 2010. Microcredit, Poverty, and Empowerment: Exploring the Connections. PGDT. Vol 2010/ 9, pp. 356-391.

Siddique, M.A.B. 1998. Gender issues in poverty alleviation: a case study of Bangladesh. International Journal of Social Economics. Vol 25 (6/7/8), pp. 1095 - 1111.

Siringi, E.M.. 2011. Women's small and medium enterprises for poverty alleviation in Sub-Saharan Africa. Management Research Review. Vol 34/2, pp. 186- 206.

Sriyuningsih, Nuniek. 2003. Makalah: Penelitian yang Berperspektif Gender, pada Pelatihan Metodologi Penelitian Berperspektif Gender. Lembaga Penelitian, UNSOED: Purwokerto.

Teerakul, Nuttamon; Renato A. Villano; Fiona Q. Wood; dan Stuart W. Mounter,. 2012. "A framework for assessing the impacts of community-based enterprises on household poverty", Journal of Enterprising Communities: People and Places in the Global Economy. Vol 6/1, pp. 5-27.

Thierry, Astrid Ruiz. 2007. The elephant in the room: gender and export-led poverty reduction. Management Decision. Vol 45/8, pp. $1359-1376$.

Walczak-Duraj, Danuta. 2010. Social Capital of Women in Rural Areas and Their Participation in the Socio-political Life. Polish Sociological Review. Vol 172/ 2010, pp. 429-446.

Wallis, Joe and Brian Dollery. 2002. Social Capital and Local Government Capacity. Australian Journal of Public Administration. Vol 61/3, pp. 76-85.

Welshman, John. 2006. Searching for Social Capital: Historical Perspectives on Health, Poverty and Culture. The Journal of the Royal Society for the Promotion of Health. Vol 126/6, pp. 268-274. 